Original Article

\title{
Hubungan Kualitas Diet, Durasi Tidur, dan Kelelahan Kerja Terhadap Produktivitas Kerja di Masa Pandemi Covid-19
}

\section{The Relationship between Diet Quality, Sleep Duration, and Work Fatigue on Work Productivity During the Covid-19 Pandemic}

\author{
Juliana $^{1}$, Harna Harna*1, Erry Yudhya Mulyani' ${ }^{1}$, Khairizka Citra Palupi ${ }^{1}$ \\ ${ }^{1}$ Program Studi Gizi Fakultas Ilmu-Ilmu Kesehatan Universitas Esa Unggul, Indonesia \\ (email : harna@esaunggul.ac.id /Hp 081289903103)
}

\begin{abstract}
ABSTRAK
Produktivitas kerja dipengaruhi beberapa faktor seperti kualitas diet, durasi tidur, dan kelelahan kerja. Tujuan penelitian untuk mengetahui hubungan kualitas diet,durasi tidur, dan kelelahan kerja terhadap produktivitas kerja dimasa pandemi covid-19. Metode penelitian dengan desain studi cross sectional menggunakan data primer. Sampel sebanyak 52 responden berusia 17-52 tahun yang terdiri dari pekerja laki-laki dan perempuan. Variabel yang diteliti yaitu variabel independen terdiri dari kualitas diet, durasi tidur, kelelahan kerja dan variabel dependen yaitu produktivitas kerja. Kualitas diet diperoleh dari food recall 1×24 jam selama 2 hari, dan durasi tidur, kelelahan kerja, produktiivtas kerja di peroleh dengan kuesioner. Analisis data menggunakan uji korelasi Spearman karena data tidak berdistribusi normal. Hasil penelitian adanya hubungan kualitas diet dengan produktivitas kerja dimasa pandemi covid-19, adanya hubungan durasi tidur dengan produktivitas kerja, dan tidak terdapat hubungan yang signifikan kelelahan kerja dengan produktivitas kerja. Kesimpulan yang diperoleh kualitas diet dan durasi tidur pada pekerja dapat mempengaruhi produktivitas kerja dan pada kelelahan kerja tidak mempengaruhi produktivitas kerja dimasa pandemi covid-19.
\end{abstract}

Kata kunci : Pekerja, Kualitas Diet, Durasi Tidur, Kelelahan Kerja, Produktivitas Kerja

\section{ABSTRACT}

Work productivity is influenced by several factors such as diet quality, sleep duration, and work fatigue. The purpose of the study was to determine the relationship between diet quality, sleep duration, and work fatigue on work productivity during the COVID-19 pandemic. The research method is a cross sectional study design using primary data. The sample is 52 respondents aged 17-52 years consisting of male and female workers. The variables studied were independent variables consisting of diet quality, sleep duration, work fatigue and the dependent variable was work productivity. Diet quality was obtained from food recall $1 \times 24$ hours for 2 days, and sleep duration, work fatigue, work productivity were obtained by questionnaire. Data analysis used the Spearman correlation test because the data were not normally distributed. The results of the study showed that there was a relationship between diet quality and work productivity during the COVID-19 pandemic, there was a relationship between sleep duration and work productivity, and there was no significant relationship between work fatigue and work productivity. The conclusion obtained is that the quality of diet and sleep duration in workers can affect work productivity and work fatigue does not affect work productivity during the covid-19 pandemic.

Keywords : Workers, Diet Quality, Sleep Duration, Work Fatigue, Work Productivity https://doi.org/10.33860/jik.v15i4.544

(C) 2021 by the authors. Submitted for possible open access publication under the terms and conditions of the Creative Commons Attribution (CC BY SA) license (https://creativecommons.org/licenses/by-sa/4.0/). 


\section{PENDAHULUAN}

Pada masa pandemi covid-19 ini menuntut sumber daya berperan penting dalam melakukan pekerjaannya. Kondisi pandemi virus Covid 19 yang terjadi sedang dialami oleh hampir masyarakat diseluruh negara belahan dunia $^{(1)}$. Maka dari itu pendukung untuk seluruh aktivitas kerja dilakukan melalui media massa dan elektronik, dengan adanya kebijakan untuk pembatasan sosial berskala besar yang mengharuskan bagi perusahaan industri yang bergerak di sektor pangan dan sektor kesehatan, untuk menerapkan kerja sesuai protokol kesehatan dengan menerapkan pembatasan jarak atau social distancing ${ }^{(2)}$.

Berdasarkan data International Labour

Organisation mengatakan bahwa nilai produktivitas tenaga kerja masyarakat Indonesia posisi keempat dengan negara yang termasuk ASEAN lainnya ${ }^{(1)}$. Indonesia termasuk jumlah penduduk yang terbanyak di Asia Tenggara, sehingga dapat memberikan manfaat dalam kekuatan dan pembangunan negara serta meningkatkan perekonomian negara. Kualitas konsumsi pangan yang buruk dapat meyebabkan masalah kesehatan yang berakibat menurunnya produktivitas kerja, menurunnya produktivitas kerja mengakibatkan melemahnya daya saing, sehingga berakibat pertumbuhan ekonomi melemah ${ }^{(3)}$.

Kualitas diet digunakan untuk menilai asupan makan telah sesuai rekomendasi sesuai rekomendasi yang ditetapkan berpengaruh pada produktivitas kerja. Selain itu, pada keompok orang dewasa terutama para pekerja yang masih akif membutuhkan asupan zat gizi makro ${ }^{(4)(3)(5)}$. Durasi tidur juga dapat memberikan pengaruh pada hasil yang sejalan dengan penelitian sebelumnya yang melaporkan bahwa kekurangan tidur mempengaruhi konsentrasi, kelelahan, dan memori. Menurut penelitian sebelumnya menunjukkan bahwa durasi tidur dan produktivitas tidak menunjukkan hubungan langsung. Durasi tidur pada hari kerja tidak terkait dengan penurunan produktivitas akibat presenteeism bila disesuaikan dengan skor global PSQI, tanpa mempertimbangkan komponen durasi tidur ${ }^{(6),(7),(8)}$.

Penelitian yang dilakukan
International
menjelaskan bahwa sebanyak 58.118 sampel dari 18.828 sampel $(32,8 \%)$ di antaranya mengalami kelelahan dan berpengaruh pada produktivitas $\operatorname{kerja}^{(1)}$. Menurut penelitian sebelumnya menunjukkan bahwa kelelahan kerja penting untuk diperhatikan, karena kelelahan pada pekerja dapat berdampak terhadap penurunan produktivitas kerja dan penurunan konsentrasi kerja dapat terlihat dari kondisi kesehatan fisik dan psikis, keahlian, serta kinerja dan produktivitas dari pekerja itu sendiri ${ }^{(9)}$. Keterbaruan dari penelitian ini belum ada penelitian terkait produktivitas kerja dimasa pandemi covid-19 sehingga peneliti tertarik melakukan penelitian tersebut di masa pandemi covid-19.

\section{METODE PENELITIAN}

Penelitian ini menggunakan desain kuatitatif dengan metode studi cross sectional dan dilakukan pada Juli - Augustus 2021 di PT. Kalbe farma dengan desain data primer. Penelitian ini telah lulus kaji etik dengan nomer 028621.286/DPKEKEP/FINALEA/UEU/VIII/ 2021.

Penelitian ini menggunakan populasi seluruh responden di perusahaan PT. Kalbe Farma. Sebanyak sejumlah 52 orang pekerja yang terdiri dari pekerja laki-laki dan perempuan yang digunakan sebagai sampel penelitian yang memenuhi kriteria inklusi karyawan yang masih aktif bekerja, sampel dalam keadaan sehat fisik, bersedia menaati prosedur selama proses penelitian hingga proses penelitian berakhir, serta mampu berkomunikasi dengan baik dan kriteria eksklusi yang digunakan penelitian ini adalah mengundurkan diri sebagai subjek saat proses penelitian berlangsung, mengkonsumsi obat tidur, sedang menjalani diet khusus, menderita penyakit DM dan hipertensi, pekerja wanita yang sedang dalam kondisi hamil dan menyusui.

Metode untuk pengambilan sampel penelitian dengan purposive sampling, yaitu responden yang diikutsertakan memenuhi persayaratan inklusi dan eksklusi.

Data kualitas diet diperoleh menggunakan food recall 1 × 24 jam selama 2 hari yang dilakukan dengan wawancara kepada responden, penilaian kualitas diet yang digunakan dengan menggunakan metode penilaian dari IGS3-60. Pada durasi tidur diperoleh dengan responden mengisi kuisioner durasi tidur PSQI (Pittsburgh Sleep Quality Index) yang diberikan oleh peneliti. Kelelahan kerja diperoleh dari responden mengisi kuisioner kelelahan kerja / Subjective Self 
Rating Test dari IFRC yang diberikan peneliti melalui wawancara. Produktivitas kerja yang di peroleh dengan responden mengisi kuisioner produktivitas kerja yang diberikan oleh peneliti. Pengambilan data pada responden dilakukan secara online dengan google form untuk data food recall dilakukan secara virtual melalui zoom meeting dikarenakan kondisi pandemi covid-19.

Analisis statistik menggunakan SPSS versi 26. Analisis bivariat menggunakan uji korelasi spearman karean data yang digunakan tidak berdistribusi normal Pada analisis ini menggunakan tingkat kemaknaan 5\%.

\section{HASIL}

Berdasarkan tabel 1 diketahui bahwa karyawan PT. Kalbe Farma berjenis kelamin laki-laki sebanyak 26 orang (50\%) dan berjenis kelamin perempuan sebanyak 26 orang (50\%). Hal ini menujukan bahwa persentase jenis kelamin karyawan sama rata. Pada umur menunjukkan bahwa rata-rata umur karyawan yang paling banyak pada kelompok umur 17 35 tahun sebanyak 48 orang (94.2\%) yang termasuk dalam kategori umur remaja akhir sampai dewasa awal.

\begin{tabular}{|c|c|c|}
\hline $\begin{array}{l}\text { Karakteristik } \\
\text { Responden }\end{array}$ & n & $\begin{array}{l}\text { Presentase } \\
(\%)\end{array}$ \\
\hline \multicolumn{3}{|l|}{ Jenis Kelamin } \\
\hline Laki-laki & 26 & 50.0 \\
\hline Perempuan & 26 & 50.0 \\
\hline \multicolumn{3}{|l|}{ Umur } \\
\hline 17 - 35 Tahun & 49 & 94.2 \\
\hline $36-55$ Tahun & 3 & 5.8 \\
\hline \multicolumn{3}{|l|}{ Pendidikan } \\
\hline Tinggi & 52 & 100 \\
\hline \multicolumn{3}{|l|}{ Lama Kerja } \\
\hline$<3$ Tahun & 18 & 34.6 \\
\hline$\geq 3$ Tahun & 34 & 65.4 \\
\hline
\end{tabular}

Berdasarkan pendidikan menunjukkan bahwa pendidikan karyawan didapatkan hasil rata-rata pendidikan dengan latar belakang pendidikan tinggi yaitu latar belakang Pendidikan SMA/SMK sampai pendidikan lanjut sebanyak 52 orang (100 \%). Pada lama bekerja karyawan dapat dilihat bahwa sebanyak 34 orang $(65.4 \%)$ dari 52 karyawan menunjukkan lama bekerja selama lebih sama dengan 3 tahun, dan sebanyak 18 orang (34.6\%) kurang dari 3 tahun bekerja di PT. Kalbe Farma. Gambaran kualitas diet pada karyawan terdiri dari frekuensi dengan kategori buruk dan kurang.

Distribusi frekuensi hasil penelitian dari 52 responden memiliki kategori kualitas diet yang buruk sebanyak 49 orang (94.2\%) dan kurang sebanyak 3 orang (5.8\%). menunjukkan bahwa hasil penelitian kualitas diet dari 52 responden memiliki kategori kualitas diet yang buruk sebanyak 49 orang (94.2\%) dan kurang sebanyak 3 orang (5.8\%). Gambaran durasi tidur pada karyawan terdiri dari kategori kurang dan cukup.

Distribusi frekuensi menujukkan hasil penelitian durasi tidur dari 52 responden memiliki durasi tidur yang termasuk dalam kategori kurang sebanyak 32 orang $(61.5 \%)$ dan cukup 20 orang (38.5\%). Gambaran kelelahan kerja pada karyawan terdiri dari kategori kelelahan tingkat ringan,sedang dan berat. Kelelahan kerja dari 52 responden memiliki tingkat kelelahan kerja dengan kategori ringan sebanyak 26 orang $(50 \%)$, sedang sebanyak 25 orang $(48.1 \%)$, dan berat sebanyak 1 orang (1.95). Penelitian produktivitas kerja dari 52 responden memiliki kategori produktif sebanyak 37 orang $(71.2 \%)$ dan tidak produktif sebanyak 15 orang (28.8\%).

Penelitian bivariat menunjukkan hasil pada kualitas diet memiliki nilai $\mathrm{p}$-Value $=$ 0.012 ( $\mathrm{p}<0.05)$, dengan demikian dapat disimpulkan bahwa ada nya hubungan kualitas diet terhadap produktivitas kerja dan diperoleh nilai $\mathrm{r} 0.344$ yang artinya hubungan positif dengan korelasi cukup yaitu semakin tinggi nilai kualitas diet seseorang maka nilai produktivitas kerja juga semakin tinggi. Pada durasi tidur menunjukkan nilai p-Value 0.003 $(\mathrm{p}<0.05)$ dapat disimpulkan adanya hubungan durasi tidur terhadap produktivitas kerja dan diperoleh nilai $\mathrm{r} 0.405$ yang artinya hubungan positif dengan korelasi cukup yaitu semakin tinggi nilai durasi tidur seseorang maka nilai produktivitas kerja juga semakin tinggi. Pada niali kelelahan kerja diperoleh nilai $\mathrm{p}$-Value $0.134(\mathrm{p}<0.05)$ dapat disimpulkan tidak adanya hubungan kelelahan kerja terhadap produktivitas kerja di masa pandemi covid-19 dengan nilai $\mathrm{r}-0.211$ yang artinya hubungan negatif dengan korelasi lemah yaitu semakin rendah nilai kelelahan kerja maka semakin tinggi nilai produktivitas kerja pada pekerja (Tabel 2). 
Tabel 2. Data Frekuensi Kualitas Diet, Durasi Tidur, Kelelahan Kerja, dan Produktivitas Kerja

\begin{tabular}{lcc}
\hline Variabel & $\mathbf{n}$ & \% \\
\hline Kualitas Diet & \multicolumn{2}{l}{} \\
Buruk & 3 & 94.2 \\
Kurang & & 5.8 \\
Durasi Tidur & 32 & 61.5 \\
Kurang & 20 & 38.5 \\
Cukup & & \\
Kelelahan Kerja & 26 & 50.0 \\
Ringan & 25 & 48.1 \\
Sedang & 1 & 1.9 \\
Berat & & \\
Produktivitas Kerja & 15 & 28.8 \\
Tidak Produktif & 37 & 71.2 \\
Produktif & & \\
\hline
\end{tabular}

Tabel 3. Hubungan Kualitas Diet, Durasi Tidur, dan Kelelahan Kerja Terhadap Produktivitas Kerja Pekerja

\begin{tabular}{lcc}
\hline Variabel & \multicolumn{2}{c}{ Produktivitas Kerja } \\
\cline { 2 - 3 } & $\mathbf{p}$-Value \\
\hline Kualitas Diet & 0.344 & 0.012 \\
Durasi tidur & 0.405 & $0.003^{*}$ \\
Kelelahan Kerja & -0.211 & 0.134 \\
\hline
\end{tabular}

Pada hasil analis uji statistik multivariat menunjukkan bahwa variabel kualitas diet dengan nilai p-value 0.170 , SE 2.926 dan CI $95 \%-9.954-1.801$, durasi tidur nilai $\mathrm{p}$-value 0.006, SE 0.326 dan CI 95\% -1.593 - (-0.284), dan kelelahan kerja nilai p-value 0.096, SE 3.667 dan CI 95\% - 1.145 - 13.584 yang secara signifikan bahwa produktivitas berpengaruh pada durasi tidur, dan tidak berpengaruh pada kualitas diet dan kelelahan kerja pada pekerja (Tabel 3).

\section{PEMBAHASAN}

Pada karakteristik reponden terdapat beberapa karakteristik yang dilihat seperti jenis kelamin, usia, pendidikan dan lama bekerja. Pada penelitian yang dilakukan dengan 52 responden dengan pekerja laki-laki berjumlah Umur merupakan salah satu karakteristik demografi penting yang biasanya selalu diukur dalam penelitian, Responden yang terlihat dalam penelitian berusia 19 tahun sampai 52 tahun. Kategori usia pada tenaga kerja yang termasuk usia produktif dalam rentang usia 15 tahun sampai dengan usia 60 tahun, jika tenaga kerja usia produktif akan berpengaruh pada produktivitas kerjanya akan meningkat karena memiliki kreatifitas yang tinggi terhadap pekerjaan dengan pengetahuan dan wawasan yang lebih baik dengan tanggung jawab yang lebih tinggi terhadap tugas yang diberikan ${ }^{(10)}$. Pada penelitian yang dilakukan dengan 52 responden setelah dilakukan kategori pada tingkat pendidikan dengan distribusi frekuensi terbanyak dengan pendidikan tinggi yaitu pada lulusan SMA/SMK sesuai dengan persyaratan penerimaan tenaga kerja. Masa bekerja merupakan kurun waktu atau lamanya bekerja disuatu tempat atau perusahaan bekerja ${ }^{(11)}$. Pada penelitian yang dilakukan dengan 52 responden setelah dilakukan kategori pada tingkat pendidikan dengan distribusi frekuensi terbanyak dengan lama bekerja $\geq 3$ tahun.

Konsumsi pangan mempengaruhi karakteristik dari individu seperti usia, pendidikan dan pendapatan. Konsumsi pangan ikut berperan dalam menentukan tingkat kecukupan zat gizi seseorang. Sebagian besar responden memlikit kategori kualitas diet yang cenderung ke arah buruk.

Hasil analisis bivariat adanya hubungan yang signifikan antara kualitas diet terhadapa produktivitas kerja di masa pandemi covid-19. Sejalan dengan penelitian yang dilakukan oleh 12 diperoleh hasil analisis statistik dengan korelasi Ranks Spearman nilai $\mathrm{p}=0,004(\mathrm{p}<$ $0,05)$ diketahui bahwa adanya hubungan Pola Konsumsi dan Produktivitas Kerja Pada Pekerja di Bagian Produksi PT. Sinar Sosro Tanjung Morawa Kabupaten Deli Serdang Tahun 2018 
terdapat nilai koefisien korelasi 0,454 dengan kategori korelasi positif. Menjaga kesehatan merupakan faktor utama untuk peningkatan produktivitas tenaga kerja selaku sumber daya manusia. Berdasarkan hasil penelitian sebelumnya mengenai konsumsi makan terdapat hubungan dengan produktivitas kerja dengan uji Chi-square diperoleh hasil 0,011 menunjukkan lebih kecil dari level of significan $\alpha=0,05$ ( $p$-value $<0,05$ ) dimana adanya hubungan konsumsi makanan dengan produktivitas kerja pada pekerja wanita di PT. Karya Tanah Subur (KTS) ${ }^{(13)}$.

Kualitas diet dapat mempengaruhi produktivitas pada pekerja karena mengkonsumsi makanan yang sesuai dengan kebutuhan dan prinsip gizi seimbang akan menghasilkan tenaga sehingga konsumsi makanan yang baik dapat meningkatkan produktivitas kerja pada pekerja. Kualitas diet yang buruk karena variasi makanan yang dimakan pada pekerja disetiap harinya masih belum sesuai dengan prinsip gizi seimbang (PGS) dianjurkan untuk mengkonsumsi jenis varian makanan. Berdasarkan dari faktor yang dapat memengaruhi kualitas diet perlu dilakukan kategori status sosial ekonomi dan status gizi. Kualitas diet kategori usia dewasa dipengaruhi oleh ketersediaan dan pemilihan bahan pangan. Tenaga kerja dianjurkan untuk memperoleh gizi yang cukup dan sesuai dengan jenis atau beban pekerjaan yang dilakukan. Nilai gizi yang kurang terpenuhi dari sumber makanan yang dikonsumsi tenaga kerja seharihari dapat berdampak buruk terhadap tubuh pekerja adanya penurunan daya tahan tubuh, kemampuan fisik yang berkurang, berat badan mengalami penurunan atau bereaksi menjadi lambat.

Durasi tidur merupakan lama waktu tidur seseorang dalam satu hari. Durasi tidur dapat memberikan dampak buruk pada pekerja. Tidur termasuk dalam kebutuhan yang bersifat fisiologis untuk kebutuhan manusia ${ }^{(14)(15)}$. Dari hasil analisis statisik diperoleh hasil adanya hubungan yang signifikan antara durasi tidur dengan produktivitas kerja $\mathrm{Hal}$ ini sejalan dengan penelitian sebelumnya menunjukkan adanya hubungan yang signifikan antara durasi tidur dan produktivitas kerja diperoleh hasil Penurunan produktivitas akibat presenteeism orang dengan durasi tidur pendek, antara 5 dan 6 jam $(b=0,068, p=0,004)$ dan kurang dari 5 jam $(b=0,105, p<0,001)$, secara signifikan lebih besar. Kesehatan tidur berhubungan dengan presenteeism di Jepang ${ }^{(14)}$. Kualitas tidur subjektif, disfungsi siang hari, gangguan tidur, dan penggunaan obat tidur berhubungan dengan presenteeism, durasi tidur yang baik dapat menjadi penting bagi produktivitas pekerja. Hal tersebut didukung oleh penelitian sebelumnya yang dilakukan oleh penelitian sebelumnya dengan menggunakan metode cross-sectional menggunakan responden penelitian melibatkan karyawan berusia 18 hingga 80 tahun, mengatakan adanya hubungan antara jam tidur dan kedua ukuran produktivitas berbentuk $\mathrm{U}$, dengan kehilangan produktivitas paling sedikit di antara karyawan yang melaporkan 8 jam tidur lebih banyak kelelahan siang hari sehingga berkorelasi dengan lebih banyak ketidakhadiran dan kehadiran ${ }^{(3)}$.

Pada penelitian ini, responden rata-rata memiliki durasi tidur yang kurang baik yaitu kurang dari 7 jam ditemukan paling banyak durasi tidur yang kurang pada pekerja laki-laki, karena pekerja laki-laki rata-rata selalu begadang saat malam hari sepulang kerja maka dapat menyebabkan timbul kelelahan pada siang harinya dan terjadi penurunan aktivitas fisik.

Kelelahan kerja menjadi permasalahan yang harus ditangani dan dapat mengakibatkan timbul berbagai masalah yaitu kehilangan efisiensi dalam bekerja, penurunan pada produktivitas dan kapasitas kerja serta kemampuan kesehatan dan kemampuan bertahan tubuh dapat menyebabkan kecelakaan kerja. Suatu pola yang timbul dari suatu keadaan, yang secara umum terjadi pada setiap individu yang sudah tidak sanggup melakukan aktivitas merupakan kelelahan kerja $^{(16)}$. Kelelahan kerja diukur menggunakan metode kuesioner dengan Subjective Self Rating Test dari Industrial Fatigue Research Committe (IFRC) Jepang dimana terdapat 30 pertanyaan yang berisi tentang gejala yang dialami terkait kelelahan kerja yang dialami oleh para pekerja. Pada pengujian bivariat disimpulkan tidak adanya hubungan yang signifikan antara kelelahan kerja dengan produktivitas kerja Pada nilai rata-rata kelelahan kerja yang dialami pekerja termasuk dalam kategori kelelahan tingkat ringan dan sedang karena dengan kondisi pandemi covid-19 beban kerja yang dirasakan lebih ringan daripada kondisi sebelum adanya pandemi. Penelitian ini tidak sejalan dengan penelitian sebelumnya pada analisis statistik hubungan kelelahan dengan produktivitas kerja dengan mengunakan uji 
kolerasi didapatkan nilai pearson corerelation sebesar -0,807 dan sebesar sig 0,011 data tersebut disimpulkan hubungan kelelahan kerja dengan produktivitas tenaga kerja, kelelahan yang dialami pekerja maka berpengaruh terhadap produktivitas yang menjadi menurun ditandai dengan rasa yang dapat berpengaruh terhadap produktivitas kerja ${ }^{(17)}$. Menurut penelitian terdahulu menunjukkan adanya hubungan kelelahan dengan produktivitas tenaga kerja menggunakan uji kontingensi koefisien diperoleh nilai asosiasinya sebesar 0,398 berada pada rentang nilai $0,26-0,50$ yang berarti memiliki tingkat hubungan kategor sedang maka dapat disimpulkan adanya hubungan antara kelelahan kerja dengan produktivitas tenaga kerja pabrik krupuk CV Sumber Barokah pada bagian pengemasan ${ }^{(18)}$. Berdasarkan hasil penelitian sebelumnya juga menunjukkan adanya hubungan kelelahan kerja dengan produktivitas kerja di bagian tenun di PT. ALKATEX Tegal ${ }^{(19)}$. Penelitian yang dilakukan sebelumnya tidak sejalan dengan penelitian ini kemungkinan karena perbedaan dalam uji analisis statistik yang digunakan, perbedaan pada responden terkait karakteristik responden yang digunakan meliputi jenis kelamin, usia, masa kerja dan daerah dan tempat dilakukan untuk penelitian seperti jenis perusahaan yang dilakukan penelitian karena penelitian ini dilakukan pada perusahan farmasi obat. Berdasarkan hasil uji regresi linear berganda yang menggunakan dari variabel independen (kualitas diet, durasi tidur, dan kelelahan kerja) yang mempengaruhi nilai dari variabel dependen produktivitas kerja dapat diketahui bahwa dari keempat variabel yang memiliki hubungan yang bermakna hanya variabel durasi tidur yang dapat mempengaruhi produktivitas kerja pada pekerja.

\section{KESIMPULAN DAN SARAN}

Kesimpulan yaitu adanya hubungan kualitas diet dan durasi tidur pada pekerja terhadap produktivitas kerja dimasa pandemi covid-19 yang bermakna dan tidak terdapat hubungan kelelahan kerja terhadap produktivitas kerja di masa pandemi covid-19. Diharapkan pada penelitian selanjutnya dilakukan analisis hubungan antara status gizi pekerja serta asupan zat gizi pada responden terhadap variabel tersebut.

\section{UCAPAN TERIMA KASIH}

Penulis mengucapkan terimakasih kepada PT. Kalbe Farma yang telah mengijinkan peneliti untuk melakukan pengambilan data yang akan digunakan untuk penelitian dan seluruh pihak yang terlibat untuk menyelesaikan penelitian ini.

Manuskrip ini telah diikutsertakan pada Scientific Article Writing Training (SAWT) Batch IV,Program Kerja GREAT 4.1e, Program Studi S1 Gizi, FIKES Universitas Esa Unggul dengan dukungan fasilitator: Dudung Angkasa, S.Gz., M.Gizi, RD; Khairizka Citra Palupi, S.Gz., M.S; Laras Sitoayu, S.Gz.,MKM, RD, beserta tim dosen prodi Ilmu Gizi lainnya. SAWT Batch IV juga mendapat dukungan dana dari Universitas Esa Unggul.

\section{DAFTAR PUSTAKA}

1. ILO. Health and Safety in Work Place for Productivity. Geneva: International Labour Office.; 2013.

2. Yusup DK, Badriyah M, Suyandi D, Asih VS. Pengaruh bencana Covid-19, pembatasan sosial, dan sistem pemasaran online terhadap perubahan perilaku konsumen dalam membeli produk retail. http://digilib uinsgd ac id. 2020;1(1):1-10.

3. Stefan et al. Association Between Sleep and Productivity Loss Among 598676 Employees From Multiple Industries. American Journal of Health Promotion. 2018;32(4):1091-4.

4. Yoshiki Ishibashi M. Association between work productivity and sleep health: A crosssectional study in Japan. Sleep Health. 2020;6(3):270-6.

5. Harna H, Kusharto CM, Roosita K. Intervensi Susu Tinggi Protein Terhadap Tingkat Konsumsi Zat Gizi Makro Dan Status Gizi Pada Kelompok Usia Dewasa. Media Kesehatan Masyarakat Indonesia. 2017;13(4):354.

6. Ishibashi Y, Shimura A. Association between work productivity and sleep health: a crosssectional study in Japan. Sleep health. 2020;6(3):270-6.

7. Harna H, Irawan AMA, Swamilaksita PD, Sa'pang M. Perbedaan Durasi Tidur, Asupan Energi dan Zat Gizi Makro pada Anak Obesitas dan Non Obesitas. Jik (Jurnal Ilmu Kesehatan). 2021;5(1):155-60.

8. Irawan AMA, Umami Z, Yusuf AM, Harna H. Aktivitas fisik, durasi tidur dan tingkat kecukupan energi pada anak obesitas di SD Islam Al Azhar 1. Jurnal Al-Azhar Indonesia: Seri Sains dan Teknologi. 2020;5(4):186-90.

9. Nurlifaiz. Faktor-Faktor Yang Berhubungan Dengan Kelelahan Kerja Pada Pekerja Bagian 
Operator Spbu Di Kecamatan Ciputat Tahun 2014. 2014;

10. Suyono, Bambang dan Hermawan H. Analisis Faktor-faktor yang Mempengaruhi Produktivitas Tenaga Kerja pada Industri Kerajinan Kulit di Kabupaten Magetan. Jurnal Ekomaks. 2013;vol.2:no.2.

11. Tarwaka. Dasar-dasar Keselamatan Kerja Serta Pencegahan Kecelakaan di Tempat Kerja. Surakarta: Harapan Press; 2012.

12. Putra MRP. Hubungan Status Gizi dan Pola Konsumsi dengan Produktivitas Kerja pada Pekerja Di Bagian Produksi PT. Sinar Sosro Tanjung Morawa Kabupaten Deli Serdang Tahun 2018. 2018;

13. Rosmalinda NIM. Hubungan anemia dan konsumsi makanan dengan produktivitas kerja pada buruh wanita di pt. karya tanah subur (kts) kecamatan kaway xvikabupaten aceh barat. Universitas Teuku Umar Meulaboh; 2013.

14. Tarihoran, A., Muttaqin, A. dan Mulyani Y. Hubungan Kualitas Tidur dengan Kadar Gula Darah pada Pasien Diabetes Mellitus Tipe 2. Jurnal Caring, 1. 2015;

15. Wati S, Harna H, Nuzrina R, Sitoayu L, Dewanti LP. Kebiasaan sarapan, kualitas tidur, dan dukungan orangtua terhadap konsentrasi belajar selama pandemi covid 19. Ghidza: Jurnal Gizi dan Kesehatan. 2021;5(1):24-35

16. Sutalasana. Teknik Tata Cara Kerja. Bandung: TI - ITB; 2012.

17. Umyati A, Febianti E, Kurniawati A. ANALISIS HUBUNGAN KELELAHAN DENGAN PRODUKTIVITAS KERJA DI DIVISI TEKNIK PT. ASDP-MERAK. Journal Industrial Servicess. 2019;4(2).

18. Verawati L. Hubungan tingkat kelelahan subjektif dengan produktivitas pada tenaga kerja bagian pengemasan di cv sumber barokah. The Indonesian Journal of Occupational Safety and Health. 2016;5(1):51-60.

19. Muizzudin A. Hubungan Antara Kelelahan Kerja Dengan Produktivitas Kerja Pada Tenaga Kerja Bagian Tenun Di PT Alkatex Tegal Tahun 2013. Jurnal Tegal: Fakultas Kesehatan Masyarakat Universitas Negeri Semarang. 2013; 